\title{
Sorting of Drosophila small silencing RNAs partitions microRNA* strands into the RNA interference pathway
}

\author{
MEGHA GHILDIYAL, ${ }^{1,4}$ JIA XU, ${ }^{2,4}$ HERVÉ SEITZ, $^{1,5,6}$ ZHIPING WENG, $^{3}$ and PHILLIP D. ZAMORE ${ }^{1}$ \\ ${ }^{1}$ Howard Hughes Medical Institute, Department of Biochemistry and Molecular Pharmacology, University of Massachusetts Medical School, \\ Worcester, Massachusetts 01605, USA \\ ${ }^{2}$ Department of Biomedical Engineering, Boston University, Boston, Massachusetts 02215, USA \\ ${ }^{3}$ Program in Bioinformatics and Integrative Biology, University of Massachusetts Medical School, Worcester, Massachusetts 01605, USA
}

\begin{abstract}
In flies, small silencing RNAs are sorted between Argonaute1 (Ago1), the central protein component of the microRNA (miRNA) pathway, and Argonaute2 (Ago2), which mediates RNA interference. Extensive double-stranded character-as is found in small interfering RNAs (siRNAs) - directs duplexes into Ago2, whereas central mismatches, like those found in miRNA/miRNA* duplexes, direct duplexes into Ago1. Central to this sorting decision is the affinity of the small RNA duplex for the Dcr-2/R2D2 heterodimer, which loads small RNAs into Ago2. Here, we show that while most Drosophila miRNAs are bound to Ago1, miRNA* strands accumulate bound to Ago2. Like siRNA loading, efficient loading of miRNA* strands in Ago2 favors duplexes with a paired central region and requires both Dcr-2 and R2D2. Those miRNA and miRNA* sequences bound to Ago2, like siRNAs diced in vivo from long double-stranded RNA, typically begin with cytidine, whereas Ago1-bound miRNA and miRNA* disproportionately begin with uridine. Consequently, some pre-miRNA generate two or more isoforms from the same side of the stem that differentially partition between Ago1 and Ago2. Our findings provide the first genome-wide test for the idea that Drosophila small RNAs are sorted between Ago1 and Ago2 according to their duplex structure and the identity of their first nucleotide.
\end{abstract}

Keywords: microRNA; miRNA; siRNA; Argonaute; RNA interference; RNAi; small RNA sorting

\section{INTRODUCTION}

In animals, microRNAs (miRNAs) regulate the stability and rate of translation of mRNAs, whereas small interfering RNAs (siRNAs) silence transposons, defend against viral pathogens, and regulate mRNA expression (Ghildiyal and Zamore 2009). Both miRNAs and siRNAs derive from longer double-stranded RNA (dsRNA) precursors, which are cleaved by RNase III dsRNA-specific endonucleases. miRNA production begins in the nucleus, where long primary miRNAs, transcribed by RNA polymerase II, are converted into $\sim 65$ nucleotides (nt) pre-miRNA hairpins

\footnotetext{
${ }^{4}$ These authors contributed equally to this work.

Present addresses: ${ }^{5}$ Laboratoire de Biologie Moléculaire Eucaryote (LBME), Université de Toulouse, UPS, F-31000 Toulouse, France; and ${ }^{6}$ CNRS, Laboratoire de Biologie Moléculaire Eucaryote (LBME), F-31000 Toulouse, France.

Reprint requests to: Phillip D. Zamore, Howard Hughes Medical Institute, University of Massachusetts Medical School, LRB 822, 364 Plantation Street, Worcester, MA 01605, USA; e-mail: phillip.zamore@umassmed. edu; fax: (508) 856-2003.

Article published online ahead of print. Article and publication date are at http://www.rnajournal.org/cgi/doi/10.1261/rna.1972910.
}

by the RNase III ribonuclease, Drosha, aided by a doublestranded RNA-binding domain (dsRBD) partner protein (Lee et al. 2003; Denli et al. 2004; Gregory et al. 2004; Han et al. 2004; Zeng et al. 2005; Han et al. 2006). A minority of pre-miRNAs - mirtrons-correspond to entire introns and are excised from their primary transcripts by the premRNA splicing pathway (Okamura et al. 2007; Ruby et al. 2007a). Pre-miRNAs are then exported to the cytoplasm (Yi et al. 2003; Bohnsack et al. 2004; Lund et al. 2004), where they are processed by a second RNase III enzyme, Dicer, together with its dsRBD partner protein, into $\sim 22$ nt-long miRNA/miRNA* duplexes (Grishok et al. 2001; Hutvágner et al. 2001; Ketting et al. 2001; Chendrimada et al. 2005; Förstemann et al. 2005; Jiang et al. 2005; Maniataki and Mourelatos 2005; Saito et al. 2005; Lee et al. 2006; Melo et al. 2009).

siRNA production also requires Dicer, which excises 21-nt siRNA duplexes, comprising a guide and passenger strand, from long dsRNA formed by the base pairing of complementary sense and antisense transcripts, convergently transcribed mRNAs, or by the intramolecular base pairing of long, self-complementary RNAs. Such endogenous dsRNAs 
yield endo-siRNAs. Similarly, exogenous dsRNA, introduced experimentally or by viral infection, are converted by Dicer to exo-siRNAs.

In Drosophila melanogaster, Dicer-1 (Dcr-1) converts pre-miRNAs into miRNA/miRNA* duplexes; Dicer-2 (Dcr-2) converts long dsRNA into 21-nt siRNA duplexes (Zamore et al. 2000; Bernstein et al. 2001; Lee et al. 2004). The use of different Dicer proteins to generate miRNAs and siRNAs may minimize competition between the two pathways, so that an RNAi defense to viral infection does not perturb miRNA production.

All small silencing RNAs function bound to Argonaute proteins. Argonaute proteins display nucleotides $2-8$ of the small RNA guide in a prehelical geometry that confers on this region special importance in target recognition: the majority of the binding energy for target binding is contributed by this "seed" sequence (Jackson et al. 2003; Lewis et al. 2003; Haley and Zamore 2004; Rajewsky and Socci 2004; Grun et al. 2005; Krek et al. 2005; Lewis et al. 2005; Lim et al. 2005; Jackson et al. 2006; Ameres et al. 2007; Grimson et al. 2007; Wang et al. 2008; Parker et al. 2009). In flies, miRNAs are loaded from miRNA/miRNA* duplexes into Argonautel (Ago1), whereas siRNAs are loaded from guide/passenger duplexes into Argonaute2 (Ago2) (Hammond et al. 2000; Okamura et al. 2004; Rand et al. 2004; Matranga et al. 2005; Miyoshi et al. 2005; Rand et al. 2005; Kim et al. 2006; Leuschner et al. 2006). Two binary choices accompany loading of small RNAs into Argonaute proteins in Drosophila: the choice of Ago1 versus Ago2 and the selection of one of the two strands of the duplex as a miRNA or guide strand (Khvorova et al. 2003; Schwarz et al. 2003).

Although fly miRNAs are overwhelmingly associated with Ago1 and siRNAs with Ago2, small RNA production and Argonaute loading are uncoupled (Förstemann et al. 2007; Tomari et al. 2007). Instead, miRNA and siRNA duplexes are actively partitioned between Ago1 and Ago2 according to their structure. Extensive double-stranded character directs duplexes, such as siRNAs, into Ago2, which mediates RNAi, whereas bulges and mismatches, like those found in miRNA/miRNA* duplexes, are sorted into Agol (Kawamata et al. 2009). Central to this sorting decision is the affinity of the small RNA duplex for the Dcr-2/R2D2 heterodimer, which loads small RNAs into Ago2 (Liu et al. 2003; Tomari et al. 2004a,b, 2007). Central mismatches reduce binding of small RNA duplexes by the Dcr-2/R2D2 heterodimer, antagonizing Ago2 loading and promoting loading into Ago1 (Förstemann et al. 2007; Tomari et al. 2007; Kawamata et al. 2009). The function of the Dcr-2/R2D2 heterodimer in Ago2 loading is separate and distinct from its role in dicing siRNAs from long dsRNA: Dcr-2 bearing a glycine to arginine substitution (G31R) in its helicase domain cannot dice, but can still load siRNA into Ago2 (Lee et al. 2004).

Increasingly, this simple picture of small RNA strand choice is at odds with the intracellular abundance, process- ing accuracy, and evolutionary conservation of miRNA* strands. First, some evolutionarily conserved miRNAs are less abundant than their miRNA* strands, which appear to be evolving regulatory functions (Ruby et al. 2007b). Second, miRNA ${ }^{*} 5^{\prime}$ ends are far more precisely defined than their $3^{\prime}$ ends, suggesting selective pressure to generate an accurate seed region-implying that they have regulatory targets (Ruby et al. 2007b; Okamura et al. 2008c; Seitz et al. 2008). Third, there is mounting evidence that some miRNA*s may have regulatory potential (Ro et al. 2007; Okamura et al. 2008c; Lin et al. 2009), and fly miRNA* strands are evolutionarily conserved, albeit not to the same extent as miRNAs (Okamura et al. 2008c). Thus, miRNA* strands may regulate gene expression, rather than serve merely as carriers for loading the miRNA strand. Such a mechanism would make small RNA biogenesis more efficient, with each pre-miRNA producing two different regulatory small RNAs. Nonetheless, miRNAs are typically far more abundant than their miRNA* counterparts, and regulation by low abundance Ago1-small RNA complexes has not been reported in flies.

Here, we show that while most Drosophila miRNAs are bound to Agol in vivo, most miRNA* strands accumulate bound to Ago2. Partitioning of miRNAs into Agol and Ago2 provides a wide-scale in vivo test for the previously proposed principles for small RNA sorting in flies: miRNAs and miRNA* strands are sorted between the two Argonaute proteins according to the structure of their small RNA duplex, a process that requires both Dcr-2 and R2D2. Like the exo-siRNAs that direct RNAi, miRNA* strands bound to Ago2 typically begin with cytidine, whereas Ago1-bound miRNAs usually begin with uridine. Thus, the identity of the first nucleotide of a small RNA plays a role in its sorting in flies, as previously reported for plants. Finally, miRNA*s bound to Ago2 are more abundant than siRNAs that direct RNAi, suggesting that they function to silence target RNAs.

\section{RESULTS}

\section{miRNAs and miRNA*s partition differentially between Ago1 and Ago2}

We used high throughput sequencing of 18-29-nt RNA from fly heads to determine the small RNA profile and distribution of small RNAs between Agol and Ago2 in this complex somatic structure (Supplemental Table 1). Unlike other fly tissues, heads express little, if any, Piwi-interacting RNA, allowing us to focus on small RNAs bound to Ago1 or Ago2 (Ghildiyal et al. 2008). Of the $\sim 1.6$ million genome-matching small RNAs sequenced (excluding annotated noncoding RNAs such as $2 \mathrm{~S}$ ribosomal RNA), $90.2 \%$ were derived from pre-miRNAs (Fig. 1A). In parallel, we used an Ago1 monoclonal antibody (Miyoshi et al. 2005) to immunoprecipitate Ago1-associated small RNAs from fly head extracts. Nearly $97 \%$ of the $>5.03$ million 
A

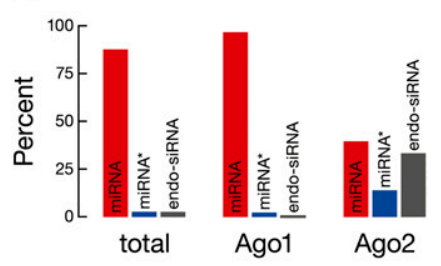

B
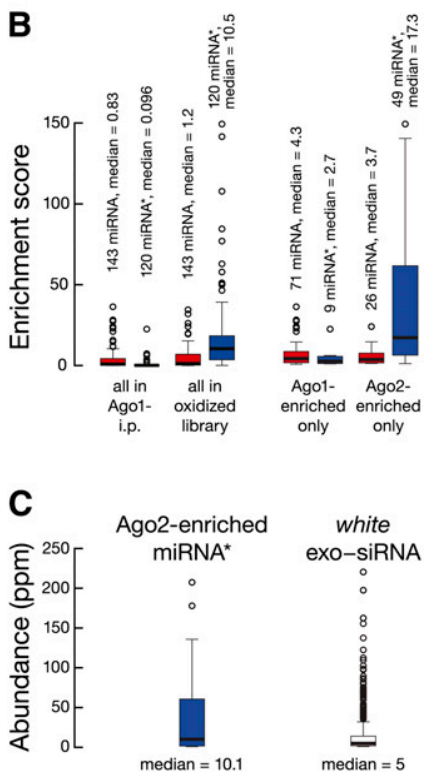

FIGURE 1. miRNA $^{*}$ s are loaded in Ago2. (A) Relative abundance of miRNA, miRNA*, and endo-siRNAs among total fly head small RNA, Ago1-bound small RNAs-inferred from co-immunoprecipitation with Ago1, and Ago2-bound small RNAs-inferred from their presence in an oxidized small RNA library. $(B)$ Box plots illustrating the enrichment scores for all miRNA and miRNA associated with Ago1 (i.e., in the Ago1 immunoprecipitate) or Ago2 (i.e., in the oxidized library) and for miRNA and miRNA* that were significantly $(P \leq 0.01)$ associated with Ago1 or Ago2. For miRNA* enriched in Ago2, six outliers with enrichment scores greater than 150 are not shown: $\operatorname{miR}-92 \mathrm{a}^{*}($ score $=1206), \operatorname{miR}-308^{*}($ score $=649)$, miR-998* $($ score $=598), \operatorname{miR}-315^{*}($ score $=514), \operatorname{miR}-2 \mathrm{a}-2^{\star}($ score $=309)$, and miR-33* (score $=304)$. (C) Box plots illustrating the abundance of Ago2-enriched miRNA* and white exo-siRNAs in the total RNA library. For miRNA* enriched in Ago2, 18 outliers with abundance greater than $250 \mathrm{ppm}$ are not shown, including miR- $8^{\star}(2748 \mathrm{ppm})$ and $\mathrm{miR}-34^{\star}(1747 \mathrm{ppm})$.

small RNA reads associated with Agol were miRNAs; only $2.2 \%$ were miRNA $^{\star}$ strands (Fig. $1 \mathrm{~A}$ ).

Ago2-loaded guide strands acquire a $3^{\prime}$ terminal 2'-Omethyl modification after their corresponding passenger strand is discarded (Horwich et al. 2007; Saito et al. 2007). To enrich for Ago2-loaded small RNAs, we oxidized the 18-29 nt RNAs prior to library preparation, a treatment that excludes from the library most Agol-loaded small RNAs, which bear 2',3' hydroxyl termini, but allows sequencing of Ago2-loaded small RNAs, because their $2^{\prime}$-O-methyl modification protects them from reaction with $\mathrm{NaIO}_{4}$ (Ghildiyal et al. 2008; Seitz et al. 2008). In general, the pre-miRNA-derived small RNAs associated with Agol correlated well with the total small RNA profile ( $r=0.91$ for miRNAs; $r=0.70$ for miRNA ${ }^{\star}$ strands), supporting the view that the majority of small RNAs in fly heads accumulate because they are bound to Agol. However, a global fit of the sum of the miRNA and miRNA* species detected in the Agol immunoprecipitation and the miRNA and miRNA* species detected in the library prepared from oxidized RNA more closely recapitulated the total small RNA profile $(r=0.91$ for miRNAs; $r=0.85$ for miRNA* strands), suggesting that Ago2-bound miRNA and/or miRNA* species are a significant component of the total pre-miRNA-derived small RNA population.

siRNAs were previously identified as the major class of Ago2-associated endogenous small RNAs in flies (Chung et al. 2008; Czech et al. 2008; Ghildiyal et al. 2008; Kawamura et al. 2008; Okamura et al. 2008a,b). Yet, the population of Ago2-associated small RNAs contained more miRNA plus miRNA* combined $(53.2 \%)$ than endosiRNAs (33.2\%) (Fig. 1A). Thus, the identity of the Dicer paralog that generates a small RNA does not determine the Argonaute protein into which it is loaded. Compared to the total small RNA population-where miRNAs represented $\sim 87.5 \%$ of all small RNAs, but miRNA ${ }^{\star}$ reads were just $2.6 \%$-miRNAs were underrepresented $(39.4 \%)$ and miRNA ${ }^{\star}$ ( $\left.13.8 \%\right)$ were overrepresented among the Ago2associated small RNA sequences. The abundance of premiRNA-derived small RNAs associated with Ago2 calls into question the prevailing view that $\mathrm{Ago} 2$ is restricted to the RNAi pathway.

In general, Ago2 was significantly depleted of miRNAs and enriched for miRNA* sequences $\left(P \leq 2.2 \times 10^{-16}\right)$. Conversely, Agol was significantly depleted of miRNA* sequences and enriched for miRNAs $\left(P \leq 2.2 \times 10^{-16}\right)$. For some of these-especially miRNAs - more of a particular small RNA was present in Agol than in Ago2, but more of that small RNA was associated with Ago2 than would be expected by chance. In all, 26 miRNAs and 49 miRNA $^{*}$ s were significantly $(P \leq 0.01)$ enriched in Ago2, whereas 71 miRNAs and 9 miRNA $^{*}$ s were significantly $(P \leq 0.01)$ enriched in Agol (Fig. 1B). Of the 49 miRNA $^{*} s$ enriched in Ago2, 32 had their corresponding miRNA enriched in Agol, while 15 had their miRNA enriched in Ago2. Among the examples illustrated in Figure 2, the miRNAs bantam and miR-308 were enriched in Agol, whereas bantam ${ }^{*}$ and miR-308* were enriched in Ago2. Supplemental Table 2 reports the enrichment or depletion of individual miRNAs and miRNA* species between the two Drosophila Argonaute proteins.

Although generally less abundant than miRNAs bound to Ago1, miRNA* isoforms (i.e., all of the species derived from the same side of the stem of a single pre-miRNA and sharing a common seed) bound to Ago2 were equally or more abundant than other small RNAs that exert their regulatory functions through Ago2, including the well-studied 


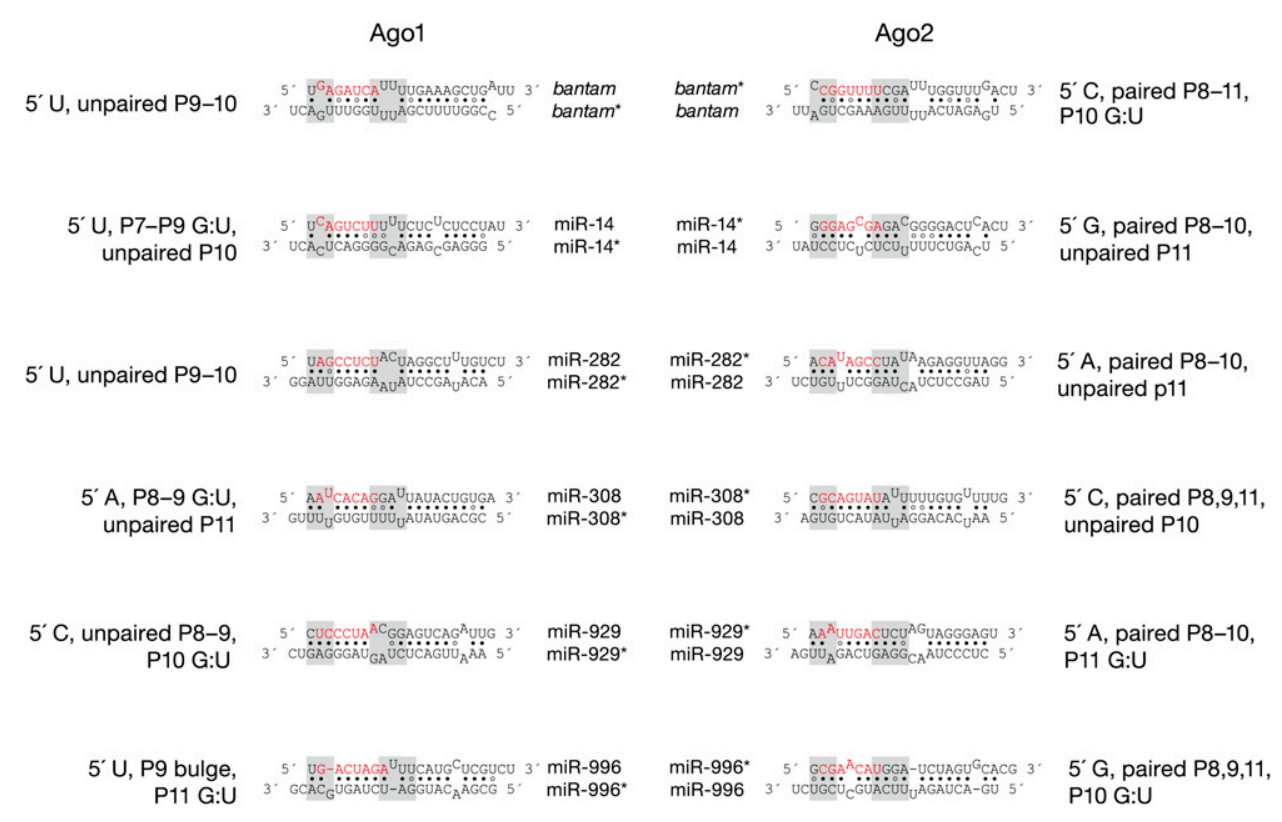

FIGURE 2. Exemplary miRNA and miRNA* duplexes. Typical miRNA/miRNA* duplexes load their miRNA strands into Agol and their miRNA $^{*}$ strands into Ago2. The examples here correspond to duplexes whose miRNA strand was significantly $(P \leq 0.01)$ enriched in Agol and whose miRNA ${ }^{\star}$ strand was enriched in Ago2. These duplexes present different structures to the Agol and Ago2 sorting machinery, as the prospective guide strand occupies a unique position during Argonaute loading. When viewed with the miRNA strand as the guide and the miRNA $^{*}$ strand as the passenger, the duplex presents a structure with central bulges, mismatches, and G:U wobbles, but when the miRNA* strand will become the guide and the miRNA strand serves as the passenger, the duplexes present more stably paired central regions. The duplexes are drawn using the guide isoform that was most abundant for the specific Argonaute protein paired to the most abundant passenger sequence detected in the total small RNA library. Red text, seed sequence; shaded bars highlight position that are significantly different between Ago1- and Ago2-loaded guides (see Fig. 4).

exo-siRNAs derived from an inverted repeat transgene that fully silences the white gene via the RNAi pathway (Lee and Carthew 2003). The median abundance for miRNA* isoforms enriched in Ago2 was more than twice that of the median abundance for white exo-siRNAs bound to Ago2, and 18 miRNA $^{*}$ were more abundant than the single most abundant white exo-siRNA detected in the same fly heads. (These 18 miRNA $^{\star}$ s are outliers whose abundance was too large to display on the box plot in Fig. 1C.) In fact, the abundance of a single miR- $8^{\star}$ isoform alone (2748 parts per million $[\mathrm{ppm}])$, was nearly two-thirds of the aggregate abundance of all antisense white exo-siRNAs (4273 ppm), whose concentration in heads is sufficient to phenocopy a strong loss-of-function white mutation. Summing the isoforms of each miRNA*, 25 miRNA $^{*}$ s were more abundant than all antisense white exo-siRNAs combined.

\section{The siRNA-loading machinery sorts miRNA* strands into Ago2}

Apart from its function in producing siRNAs, Dcr-2 acts with its double-stranded RNA-binding domain protein partner, R2D2, to both load small RNA duplexes into Ago 2 and determine the identity of guide and passenger strands. Thus, both Dcr-2 and R2D2 are required to load Ago2 with siRNAs derived from exogenous dsRNA (exo-
siRNAs), such as those derived from a long inverted repeat transcript designed to silence white mRNA expression (Lee et al. 2004; Förstemann et al. 2005). At least one Drosophila miRNA, miR-277, which associates equally with Agol and Ago2 in cultured S2 cells, requires Dcr-2 and R2D2 to load it into Ago2, even though miR-277 requires Dcr-1 to liberate it from pre-miR-277 (Förstemann et al. 2007).

Likewise, those miRNA and miRNA* sequences that were enriched in Ago2 required Dcr-2 and R2D2 for their loading (Fig. 3A). The median extent of Ago2 loading of these miRNAs declined 2.7-fold in $d c r-2^{L 811 f_{s} X}$ and 3.3-fold in $r 2 d 2^{1}$ heads, compared to wild-type; loading of miRNA* into Ago2 declined 2.1-fold in $d c r-2^{L 811 f_{s} X}$ and 3.1-fold in $r 2 d 2^{1}$. In contrast, the overall abundance of the miRNA sequences that were enriched in Agol was unaltered in $d c r-2$ or $r 2 d 2$ mutant heads.

R2D2 is stabilized by its association with Dcr-2 (Liu et al. 2003; Förstemann et al. 2007). Consequently, dcr-2 $2^{L 811 f_{\mathrm{f} X}}$ flies are also deficient in R2D2. For miRNA and miRNA* that were preferentially loaded into Ago2, the effect of the absence of Dcr-2 and R2D2 on Ago2 loading were well correlated $(r=0.828)$ (Fig. 3B,C). As expected, the abundance of miRNA and miRNA ${ }^{*}$ that were preferentially loaded into Ago1 were largely unchanged in these two mutants.

The median abundance of Ago2-enriched miRNA* sequences in the total RNA library declined $\sim 2.1$-fold in 

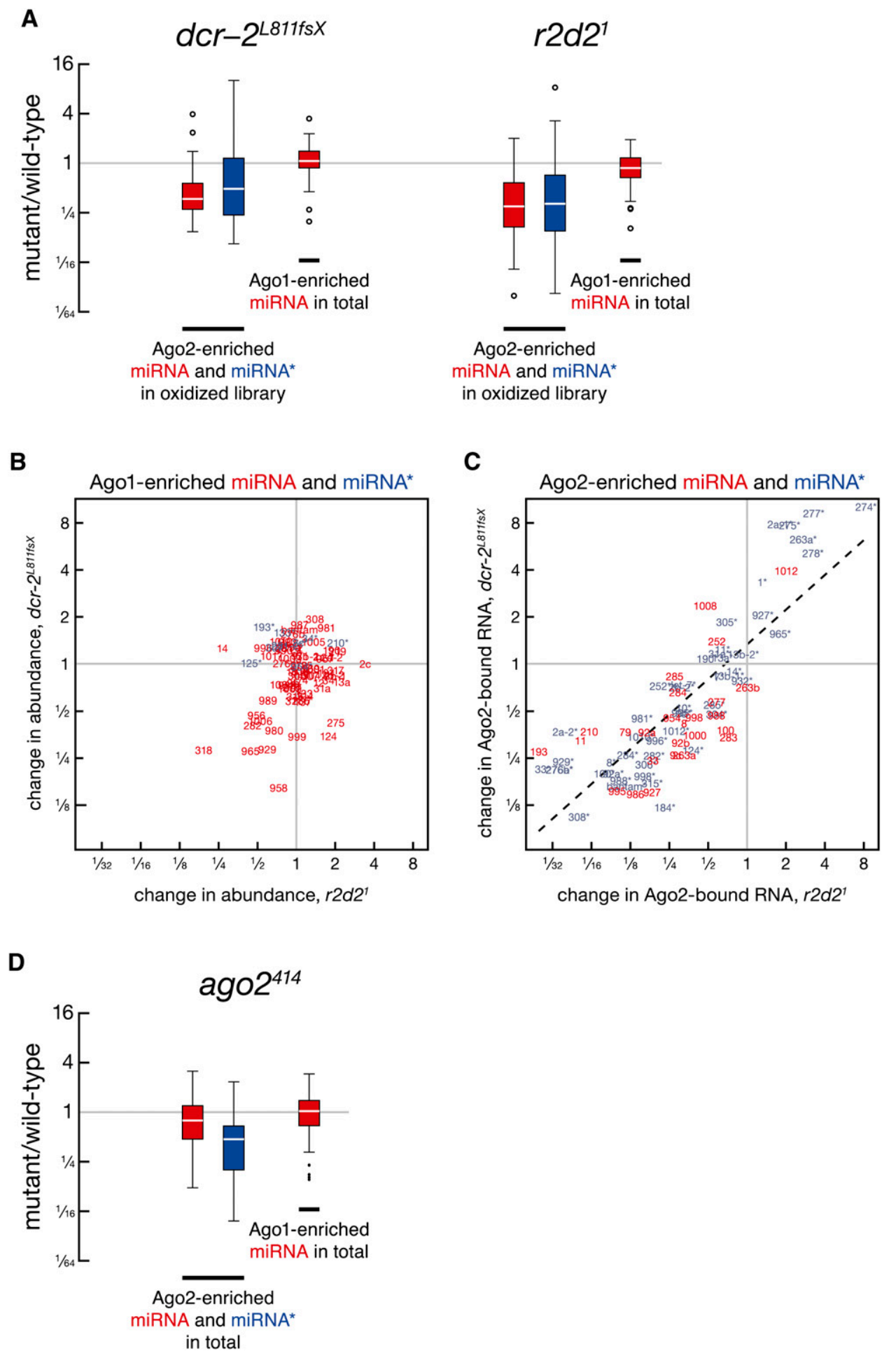

FIGURE 3. Association of miRNA* with Ago2 relies on the Ago2-loading machinery. (A) Efficient loading into Ago2 of miRNA and miRNA* strands - measured by their abundance in an oxidized small RNA library—-was diminished in heads from $d c r-2^{L 811 f s X}$ and $r 2 d 2^{1}$ mutants for miRNA and miRNA* normally enriched in Ago2, but the abundance of Agol-enriched miRNAs was unaltered, as measured in the total small RNA library. Box plots illustrate the fold-change between mutant and wild-type. $(B, C)$ The requirement for Dcr-2 and R2D2 for Ago2 loading was well correlated for miRNA and miRNA* strands preferentially loaded into Ago2. (D) The overall abundance of Ago2-enriched miRNA and miRNA* - measured in the total small RNA library—decline in ago2 mutant heads. Box plots illustrate the fold-change between mutant and wildtype in total small RNA libraries. 
the absence of Ago2 (Fig. 3D). In contrast, the median abundance of miRNA enriched in Agol was unaltered in ago $2^{414}$ mutants heads, compared to wild-type (median fold change $=1.0)$, a significant difference from the Ago2enriched miRNA ${ }^{\star}\left(P \leq 3.1 \times 10^{-8}\right)$. These data suggest that in the ago 2 mutant, those miRNA ${ }^{\star}$ species that normally are loaded into Ago2 become less stable when that Argonaute protein is not available. We envision that these miRNA ${ }^{*} /$ miRNA duplexes, while good substrates for the Ago2-loading machinery, are poor loading substrates for the Agol-loading machinery. In the absence of Ago2, miRNA ${ }^{*} /$ miRNA duplexes from which the Ago2-enriched miRNA $^{*}$ are normally loaded into Ago2 can no longer be used for this purpose. Instead, they are now used as miRNA/miRNA* duplexes-whose structure typically favors Agol loading - to load their miRNA strand into Agol. The observation that abundance of Ago2-enriched miRNA* sequences declines in ago $2^{414}$ heads supports the earlier proposal that the duplex features that promote Ago2loading are anti-determinants for Agol loading (Tomari et al. 2007; Kawamata et al. 2009).

\section{miRNA/miRNA* duplex structure determines Argonaute loading}

The Dcr-2/R2D2 heterodimer interprets the structure of a small RNA duplex, sorting centrally paired duplexes into Ago2 and leaving duplexes with an unpaired region centered on guide nucleotide 9 to enter the Ago1 loading pathway (Förstemann et al. 2007; Tomari et al. 2007). Each small RNA duplex presents two distinct duplexes to the fly sorting machinery. For example, bantam/bantam ${ }^{*}$ displays mismatches at guide positions 9 and 10 when viewed from the $5^{\prime}$ end of the miRNA, but these positions are paired when viewed from the $5^{\prime}$ end of the miRNA* strand (Fig. 2). That is, the bantam/bantam ${ }^{\star}$ and bantam ${ }^{\star} /$ bantam duplexes are not equivalent.

To evaluate if miRNA/miRNA* duplexes and miRNA*/ miRNA duplexes generally present distinct structures to the Drosophila Argonaute loading machineries, we calculated the pairing probability for each nucleotide in each miRNA/ miRNA $^{*}$ duplex that loads an Ago1- or Ago2-enriched miRNA or miRNA ${ }^{\star} / \mathrm{miRNA}$ duplex that loads an Ago1- or Ago2-enriched miRNA* (Fig. 4A). Viewed in this way, two significant $(p<0.01)$ structural differences emerge that distinguish duplexes that load Agol from those that load Ago2 (Fig. 4B,C): from the perspective of the loaded strand, Agol-loading duplexes are more likely to have an unpaired $5^{\prime}$ end and a central unpaired region that spans nucleotide positions 8-11. Conversely, Ago2-loading duplexes more likely have a paired $5^{\prime}$ end and a central region with greater double-stranded character. Ago2-loading duplexes are also more likely to have an unpaired guide $3^{\prime}$ end (Fig. 4D). Remarkably, these differences reflect the "rules" for sorting small RNA duplexes between Ago1 and Ago2 that were inferred previously from biochemical studies (Tomari et al. 2007; Kawamata et al. 2009). Thus, they provide in vivo validation of the hypothesis that Drosophila small RNA duplex structure determines its partitioning between Ago1 and Ago2.

\section{The $5^{\prime}$ terminal nucleotide of a small RNA reflects its partitioning between Ago1 and Ago2}

Arabidopsis thaliana produces ten distinct AGO proteins, and small RNAs are sorted among them according to their first nucleotide. Of the 187 annotated miRNAs in Arabidopsis, $\sim 76 \%$ begin with uridine, consistent with the idea that a 5' U steers a small RNA into plant Ago1 (Mi et al. 2008; Montgomery et al. 2008). Arabidopsis Ago2 and Ago4 preferentially load small RNAs that begin with an adenosine, whereas Ago5 favors small RNAs that begin with cytidine (Mi et al. 2008; Montgomery et al. 2008). Small RNAs in flies partition between Ago1 and Ago2 according to the structure of the duplex from which they are loaded, yet, as in plants, Drosophila miRNAs overwhelmingly begin with $U$, whereas $U$ is not overrepresented as the first nucleotide of siRNAs (Ghildiyal et al. 2008).

We analyzed the sequence composition of Ago1- and Ago2-loaded miRNA and miRNA* strands present in our small RNA libraries from fly heads. To prevent differential rates of transcription or miRNA precursor processing from skewing our analysis, for each set of small RNAs derived from a common precursor, we weighted the sequence bias of each miRNA or miRNA* isoform by its relative abundance, then averaged the sequence bias among all miRNAs or miRNA* strands, weighting each locus equally (Fig. 5).

Our analysis suggests that the first nucleotide of a fly small RNA reflects its sorting between Ago1 and Ago2. miRNAs expressed in fly heads generally began with $\mathrm{U}$ (72\%) rather than $\mathrm{A}(15.2 \%), \mathrm{C}(7.6 \%)$, or $\mathrm{G}(5.2 \%)$; for miRNAs bound to Ago1, as judged by their copurification with immunoprecipitated Ago1, $73.5 \%$ began with $U$, whereas $7.1 \%$ began with C. Among the miRNA and miRNA $^{*}$ species that were significantly $(p \leq 0.01)$ enriched in Agol relative to the total small RNA pool of fly heads, $83.9 \%$ began with $\mathrm{U}$; just $3.4 \%$ began with $\mathrm{C}$. In contrast, $49 \%$ of miRNAs that were enriched in Ago 2 began with U; $21.6 \%$ began with $\mathrm{C}$ and $21.8 \%$ began with $\mathrm{A}$, indicating a selection against a $5^{\prime} \mathrm{U}$.

miRNA* strands showed a distinctly different $5^{\prime}$ sequence bias. The miRNA* detected in fly heads typically began with A $(28.2 \%)$, C (32.1\%), or G $(22.1 \%)$, rather than $\mathrm{U}(17.6 \%)$. In contrast to this overall $5^{\prime}$ sequence bias, those miRNA* that were significantly enriched in Agol began either with $A(56.3 \%)$ or $U(29.2 \%)$; the population of miRNA* loaded into Agol was depleted of miRNA* isoforms that begin with $\mathrm{C}$.

Ago2-load miRNA* strands showed the opposite bias: they typically began with C. Nearly $58 \%$ of miRNA* strands 
A

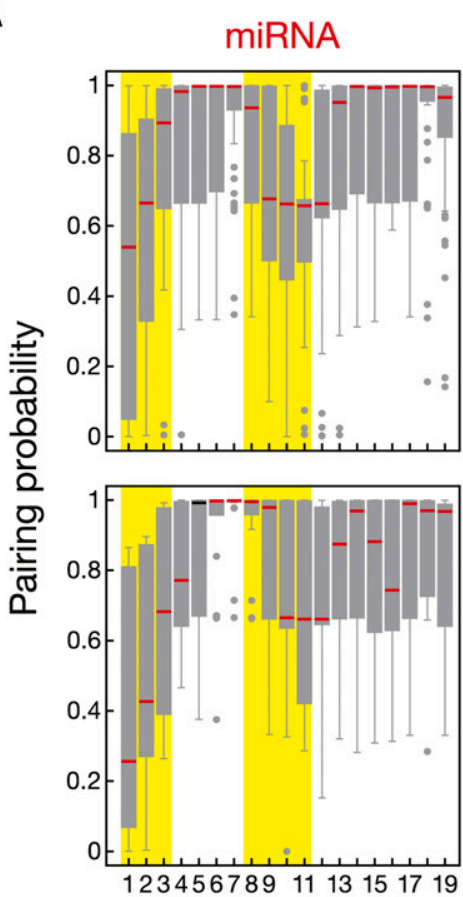

miRNA $^{\star}$
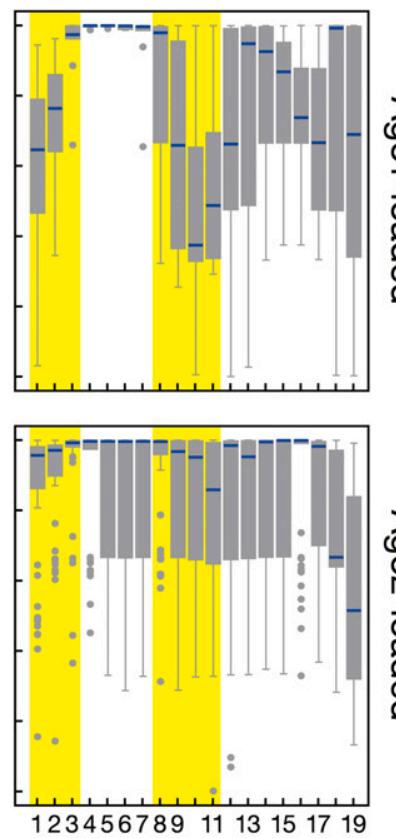

B

B Ago1 vs. Ago2 pairing

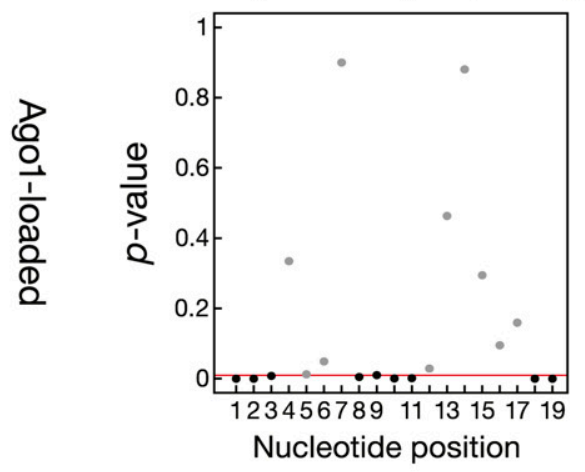

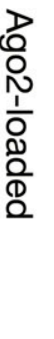

Nucleotide position from 5 ' end

C
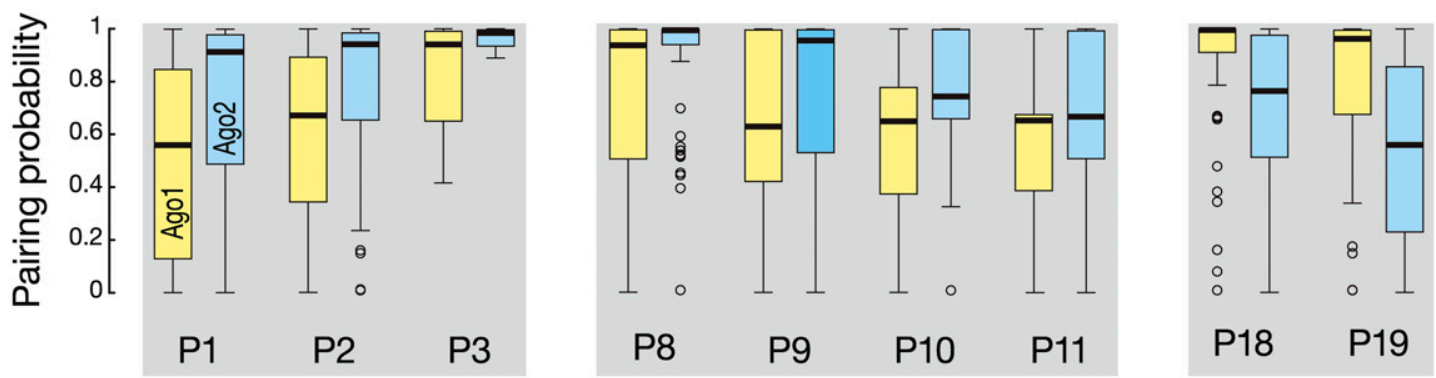

D

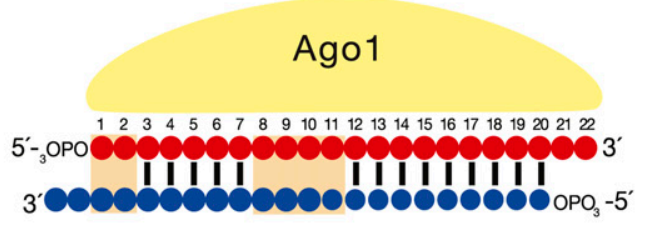

Duplex 1

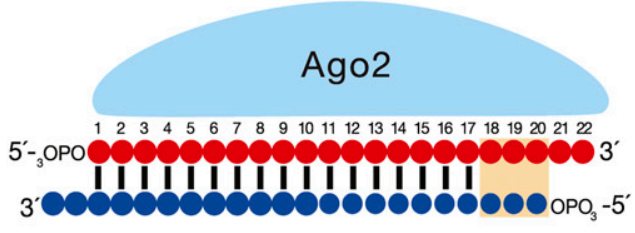

Duplex 2

FIGURE 4. Pairing profiles of Ago1- and Ago2-loaded small RNA guides. (A) Box plots illustrate the predicted double-stranded character of each nucleotide position, 1-19, for all Ago1- or Ago2-enriched miRNA or miRNA ${ }^{\star}$ strands. $(B)$ The Wilcoxon test $P$-value for each comparison was used to identify nucleotide positions that were significantly different between Agol-enriched miRNA plus miRNA* compared with Ago2-enriched miRNA plus miRNA ${ }^{\star}$. The red line indicates $P=0.01$. Gray circles, nonsignificant; black circles, significant. $(C)$ Box plots illustrate the differences in double-stranded character for each position that was significantly different in double-stranded character between Ago1- and Ago2-loaded miRNA plus miRNA ${ }^{*}$ in $B$. $(D)$ The data in $A-C$ suggest that miRNA duplexes with less stable $5^{\prime}$ ends and central mismatches act as guides for Agol and miRNA duplexes with less stable $3^{\prime}$ ends act as guides for Ago2.

enriched in Ago2 and detected in the oxidized library began with $\mathrm{C}, 15.2 \%$ began with $\mathrm{A}$, and just $7.7 \%$ began with $\mathrm{U}$, a sequence bias significantly different from the composition of nucleotides $2-18$ of the same small RNAs $(P \leq 6.7 \times$ $10^{-10}$, Fisher's exact test) and from the first nucleotide bias of miRNA* overall $\left(P \leq 6.6 \times 10^{-7}\right)$ and of those miRNA*s 


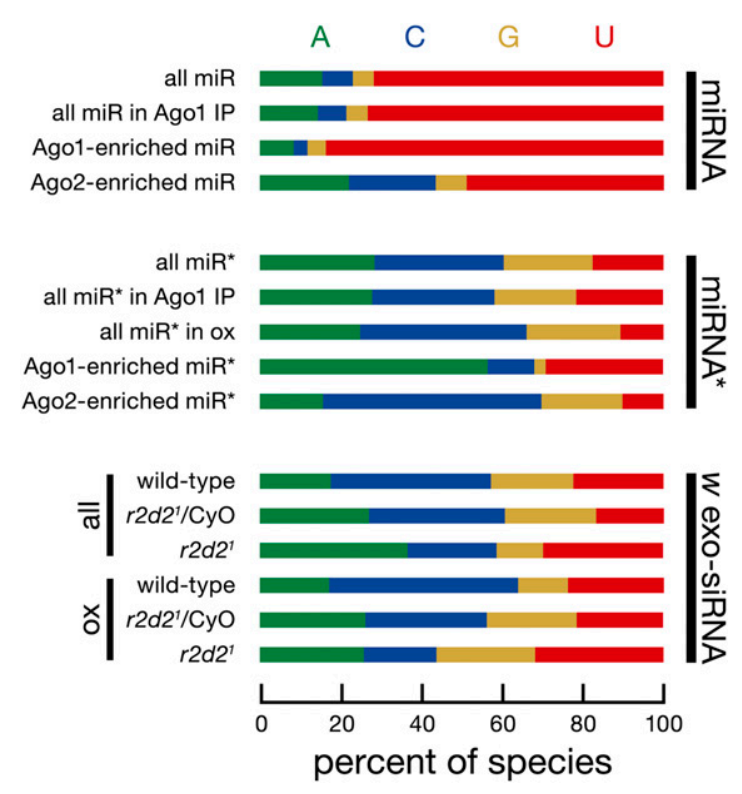

FIGURE 5. miRNAs and miRNA*s show an Argonaute-specific first nucleotide bias. miRNAs and miRNA*s associated with Agol or Ago2 differ in the bias of their first nucleotide. miRNAs generally begin with uridine; this bias increased for the subset of miRNA that were Ago1bound (measured in the Agol immunoprecipitate library), and increased further for the subset of Agol-enriched miRNAs (measured in the total small RNA library). In contrast, Ago2-enrcihed miRNAs were depleted of $5^{\prime}$ uridine in the oxidized small RNA library. miRNA $^{*}$ strands generally began with adenosine or cytidine. All miRNA $^{*}$ strands detected in the oxidized library (i.e., loaded in Ago2) or those enriched in Ago2, were significantly more likely to begin with cytidine, whereas those miRNA*s enriched in Ago1 were depleted of a $5^{\prime}$ cytidine. A $5^{\prime}$ cytidine bias was also observed for white exo-siRNAs and was diminished in $r 2 d 2^{1}$, a mutant defective in Ago2 loading.

loaded into Ago1 $(P \leq 0.017)$. Overall, $40 \%$ of the Ago1enriched miRNA or miRNA* species began with $U$, whereas $23 \%$ of the Ago2-enriched miRNA or miRNA* species began with $\mathrm{C}$.

Essentially identical sequence biases for both miRNA and miRNA $^{\star}$ were present in independent small RNA libraries from male and female heads, in libraries prepared from three distinct genetic backgrounds (Oregon R, $d c r-2^{L 811 f s X}$, $\mathrm{CyO}$, or $r 2 d 2^{1} / \mathrm{CyO}$ ), in libraries of Ago2-associated small RNAs that were prepared using either oxidation or oxidation followed by $\beta$-elimination, and in libraries processed and sequenced using two different high throughput technologies: pyrosequencing ("454") or sequencing-bysynthesis (Illumina Genome Analyzer). Together, these data suggest that, in flies, a $5^{\prime}$ terminal U promotes Ago1 loading, but discourages association with Ago2, whereas a $5^{\prime}$ terminal C directs a small RNA away from Agol and toward Ago2.

To further test this hypothesis, we analyzed the $5^{\prime}$ nucleotide composition of exo-siRNAs derived from a P-element transgene expressing a long inverted repeat corresponding to exon 3 of the white mRNA. We compared the overall population of white exo-siRNAs with those white exo-siRNAs bound to Ago2, as inferred from their presence in an oxidized small RNA library. Because the white exo-siRNA species are transcribed and diced from a common transcript, differences in their steady-state abundance likely reflect, at least in part, their different propensities to load into an Argonaute protein. Supporting this view, white exo-siRNAs levels decline $>10$-fold in vivo in a $d c r-2^{L 811 f s X}, r 2 d 2^{1}$, or $a g o 2^{414}$ mutant (T Du and PD Zamore, unpubl.). We therefore weighted each first nucleotide according to the abundance of the corresponding white exo-siRNA species.

Like Ago2-enriched miRNA*, exo-siRNAs isolated from fly heads typically began with C $(39.8 \%)$, rather than A (17.3\%), G (20.5\%), or U (22.4\%), a sequence bias significantly different from that of the corresponding strand of the dsRNA from which they are derived $(P \leq$ $1.8 \times 10^{-9}$ ). Among the white exo-siRNAs in the library prepared from oxidized small RNA-i.e., small RNAs bound to Ago2-47\% began with C. Supporting the view that the strong C-bias of exo-siRNAs reflects their association with $\mathrm{Ago} 2$, the $5^{\prime} \mathrm{C}$ bias was not observed among the 17 -fold lower amount of exo-siRNAs that remained in an $r 2 d 2^{1}$ mutant. $r 2 d 2^{1}$ mutant flies are defective in loading exo-siRNAs into Ago2 and do not silence white expression (Förstemann et al. 2005).

To further test the idea that the first nucleotide of a small RNA duplex influences its sorting between Ago1 and Ago2 in flies, we examined the loading of small RNA duplexes in vitro, using a previously described UV cross-linking assay (Tomari et al. 2007). We synthesized two miRNA duplexes, one corresponding to the authentic Drosophila let-7 miRNA/miRNA* duplex, which begins with a $5^{\prime} \mathrm{U}$, and a second in which the initial $\mathrm{U}$ of let-7 was changed to a 5' C (Fig. 6A). In parallel, we also synthesized two siRNA duplexes in which the guide strand was either authentic let-7 (paired to its reverse complement) or let-7 bearing a $5^{\prime} \mathrm{C}$ instead of a $\mathrm{U}$ (Fig. 6A). Each miRNA or guide strand was $5^{\prime}{ }^{32} \mathrm{P}$-radiolabeled, so that cross-linking identified the proteins, including Ago1 and Ago2, to which it bound when incubated in Drosophila embryo lysate.

The miRNA/miRNA* duplex containing authentic let-7 strand-i.e., let-7 that began with a $5^{\prime} \mathrm{U}$-cross-linked to Ago1 more efficiently than the let-7 variant that began with a $5^{\prime} \mathrm{C}$ (Fig. 6A,B); neither duplex detectably loaded its miRNA strand into Ago2. Moreover, when we performed cross-linking in Ago1 immunodepleted lysate, not only was Ago1 cross-linking absent, but no Ago2 cross-link appeared. We conclude that the structure of a miRNA duplex not only favors Agol loading, but actively prevents loading of the miRNA into Ago2. Moreover, the interplay between the structure of the miRNA duplex and its $5^{\prime}$ nucleotide determines its distribution between Ago1 and Ago2.

In contrast to the miRNA/miRNA ${ }^{\star}$ duplexes, the siRNA duplexes cross-linked mainly to Ago2, although some Ago1 cross-linking was clearly detected. For the siRNA duplexes, 


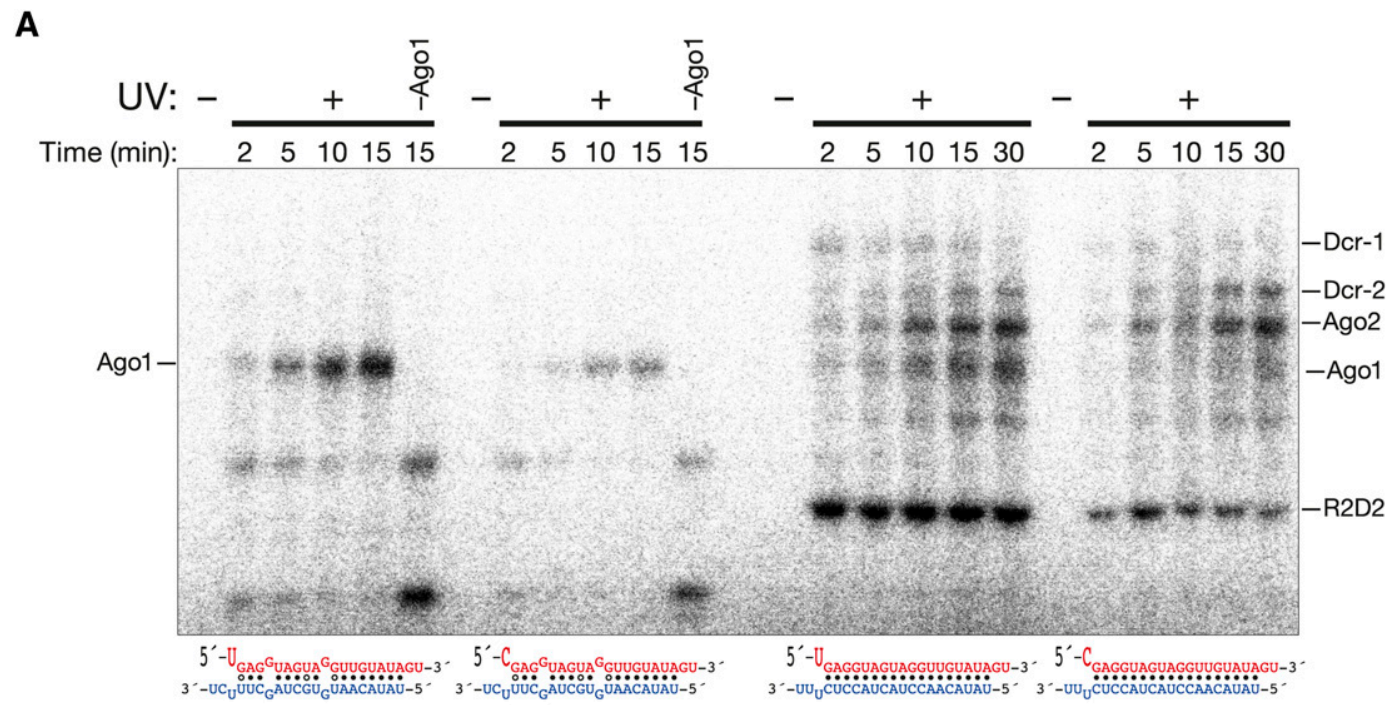

B

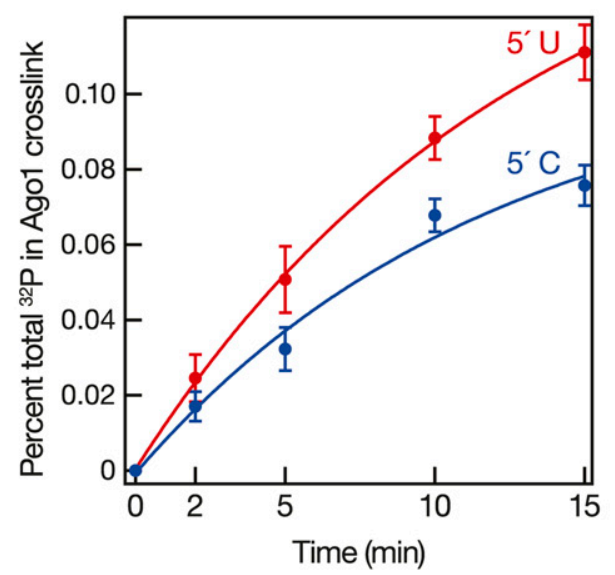

C

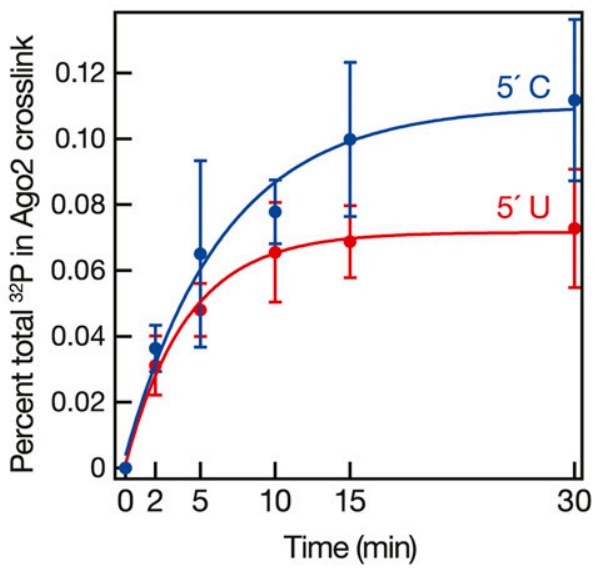

FIGURE 6. Agol prefers to load miRNAs that begin with a $5^{\prime}$ uridine, while Ago 2 prefers siRNAs that begin with a $5^{\prime}$ cytidine. $(A)$ Four small RNA duplexes were incubated with embryo lysate and then cross-linked with shortwave UV to identify small RNA-bound proteins. Representative data are shown. $(B)$ Kinetic analysis of miRNA association with Ago1, monitored by UV cross-linking. (C) Kinetic analysis of siRNA association with Ago2, monitored by UV cross-linking. In $B$ and $C$, each data point represents the average \pm standard deviation for three trials.

the influence of first nucleotide identity on the efficiency of Ago2 loading was opposite of that observed for the miRNAs: the siRNA duplex whose guide strand began with a $5^{\prime} \mathrm{C}$ loaded more efficiently into Ago2 than the siRNA duplex whose guide began with U (Fig. 6A,C). Together, these in vitro data provide strong support for the hypothesis that the enrichment for a 5' $\mathrm{U}$ among Ago1-loaded miRNAs and for a $5^{\prime} \mathrm{C}$ among Ago2-loaded miRNA, miRNA*, and siRNAs reflects a direct role for $5^{\prime}$ nucleotide identity in small RNA sorting between Ago1 and Ago2 in Drosophila.

\section{For some miRNA and miRNA*, distinct isoforms load into Ago1 and Ago2}

At least nine Drosophila pre-miRNA produce from one side of their stem two small RNAs that partition differentially between Ago1 and Ago2. Such differentially partitioning miRNA or miRNA* isoforms differ at their $5^{\prime}$ ends and therefore present subtly different duplexes to the Argonauteloading machinery. Moreover, the differentially sorting isoforms have different seed sequences, which would allow them to regulate distinct repertoires of target mRNAs. Figure 7 presents these "seed switching" miRNA and miRNA* isoforms in the context of the duplexes from which they are presumed to be loaded into Agol or Ago2. Pre-miR193 provides a particularly stunning example of such isoform-specific Argonaute loading. This pre-miRNA generates two miR-193 isoforms: one begins with a $\mathrm{U}$ and loads into Ago1, whereas a miR-193 isoform that begins at the next nucleotide, an A, loads into Ago2. PremiR-193 also generates two miR-193* isoforms. Again, the one that begins with a $U$ loads into Agol, whereas a less 


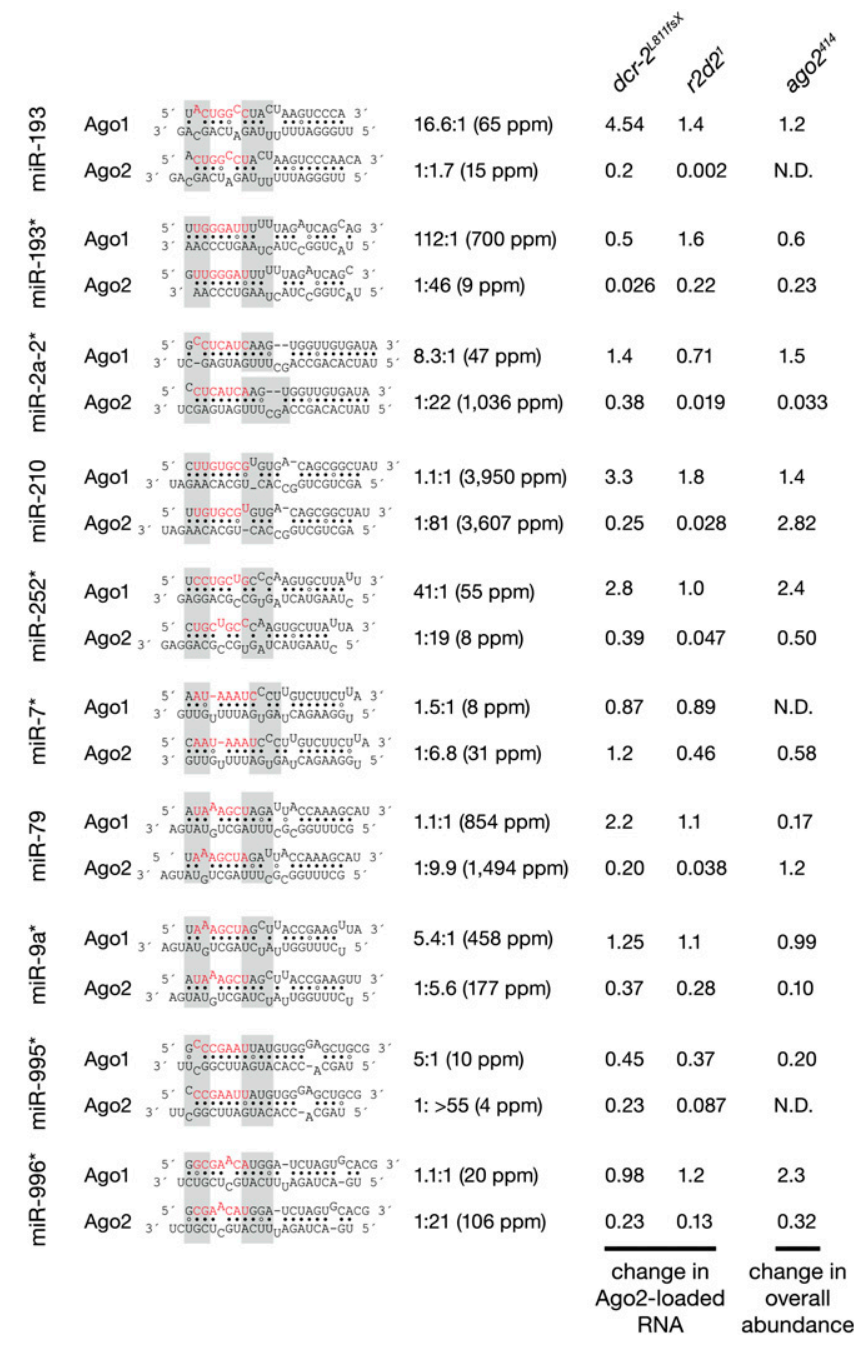

FIGURE 7. miRNA and miRNA* can switch seeds between Agol and Ago2. Depicted are miRNA/miRNA* duplexes that load distinct isoforms of their miRNA or miRNA* between Ago1 and Ago2, resulting in seed switching between Argonautes. The duplexes are drawn pairing the most abundant guide isoform associated with the particular Argonaute to the most abundant passenger strand isoform in total head small RNA library. Reads in parts per million represent the sum of all isoforms that share the same seed as detected in the total small RNA library. Ratio reports the relative number of reads for the isoform enriched in Agol: the number of reads for the isoform enriched in Ago2 as detected within either the library prepared from Agol immunoprecipitated small RNAs (Agol ratio) or oxidized small RNAs (Ago2 ratio). Red text, seed sequence; shaded bars, determinative positions for small RNA sorting between Agol and Ago2; N.D., detected in wild-type, but not detected in the ago $2^{414}$ mutant.

abundant isoform that begins at the $\mathrm{G}$ that lies immediately $5^{\prime}$ to the U loads into Ago2. This small collection of seed switching miRNA and miRNA* gives the impression that the sorting of imperfectly paired small RNA duplexes between Ago1 and Ago2 reflects a complex interplay between structural determinants or anti-determinants and first nucleotide preferences and dislikes.

\section{DISCUSSION}

Historically, miRNAs were defined as the more abundant of the small RNAs derived from the two sides of a pre-miRNA stem (Lagos-Quintana et al. 2001; Lau et al. 2001; Lee and Ambros 2001). The miRNA* strand has been proposed to be destroyed during Argonaute loading, explaining its considerably lower abundance (Khvorova et al. 2003; Schwarz et al. 2003). Yet, high depth sequencing has revealed that many miRNA* species are more abundant than some miRNA species, and miRNA/miRNA* ratios may vary dramatically among developmental stages (Ro et al. 2007; Okamura et al. 2008c).

In fly heads and ovaries, several miRNA* strands are more abundant than their annotated miRNA counterparts (Table 1). In our data sets, miR-92a was more abundant than miR-92a* in ovaries ( $3240 \mathrm{ppm}$ miRNA versus $15 \mathrm{ppm}$ miRNA ${ }^{\star}$ ), while its miR-92a* was more abundant than miR-92a in heads (24 ppm miRNA versus $106 \mathrm{ppm}$ miRNA ${ }^{\star}$ ). Likewise, miR-988 (260 ppm miRNA versus 300 ppm miRNA* in heads, but 124 ppm miRNA versus 49 ppm miRNA* in ovaries) and miR-284 (4993 ppm miRNA versus 915 ppm miRNA* in heads; 49 ppm miRNA versus $72 \mathrm{ppm}$ miRNA* in ovaries) showed distinctly different miRNA/miRNA ${ }^{\star}$ ratios in ovaries and heads. Such altered ratios may reflect different concentrations of Agol and Ago 2 or of components of their respective Argonauteloading machineries in the two organs.

\section{Sorting combines structure and sequence information}

In general, miRNAs associate with Agol and miRNA* strands associate with Ago2 in Drosophila. It is important to note that our data argues strongly against a model in which miRNA* strands bind Ago2 as a consequence of the corresponding miRNA binding Ago1. First, we can identify

TABLE 1. Pre-miRNAs whose miRNA* strands were more abundant than their miRNAs among small RNAs isolated from fly heads and fly ovaries.

\begin{tabular}{lcc}
\hline Pre-miRNA & $\begin{array}{c}\text { miRNA reads } \\
(\mathrm{ppm})\end{array}$ & $\begin{array}{c}\text { miRNA* reads } \\
(\mathrm{ppm})\end{array}$ \\
\hline Fly head & & \\
miR-10 & 771 & 1861 \\
miR-1012 & 219 & 269 \\
miR-193 & 211 & 1771 \\
miR-281-2 & 239 & 390 \\
miR-5 & 15 & 17 \\
miR-92a & 24 & 106 \\
miR-988 & 260 & 300 \\
Fly ovary & & \\
miR-10 & 29 & 83 \\
miR-1012 & 19 & 24 \\
miR-276b & 17 & 45 \\
miR-281-2 & 240 & 252 \\
miR-284 & 49 & 72 \\
\hline
\end{tabular}


six miRNAs in which both the miRNA and the miRNA* strand are enriched in Ago1 complexes in fly heads. Second, we find 15 miRNAs for which both the miRNA and miRNA* strands are enriched in Ago2 complexes. Our data suggest that each miRNA/miRNA* duplex presents two distinct structures to the sorting machinery: One in which the miRNA is the presumptive guide and one in which the miRNA* assumes that position. Evolution appears to have selected for miRNA/miRNA* duplexes that present sequence and structural features appropriate for loading Ago1, simultaneously favoring Ago2 loading when the same duplex is viewed from the perspective of the miRNA*. Consequently, miRNAs generally load into Ago1, whereas miRNA*s load into Ago2, an Argonaute protein previously thought to act only in the RNAi pathway. miRNA*s are therefore the first class of Drosophila small silencing RNAs produced by Dicer-1, but preferentially loaded into Ago2 (Fig. 8).

miRNA/miRNA* duplexes that preferentially load Ago1 are typically less stably paired at their $5^{\prime}$ ends and contain central mismatches, bulges, or $\mathrm{G}: \mathrm{U}$ wobble pairs, whereas miRNA $* /$ miRNA duplexes that preferentially load Ago2 possess more stably paired $5^{\prime}$ ends and center, but have less stably paired $3^{\prime}$ ends. In addition to structure, sequence also plays a role in small RNA sorting in flies. Ago1-bound miRNAs begin overwhelmingly with uridine, whereas Ago2-bound miRNA, miRNA*, and siRNA tend to begin with cytidine. Moreover, our in vitro cross-linking experiments show that a $5^{\prime} \mathrm{U}$ increased the efficiency of miRNA loading into Ago1, relative to a 5' C, whereas a 5' C-in the context of an siRNA duplex-increased the efficiency of Ago2 loading, relative to a $5^{\prime} \mathrm{U}$.

The $5^{\prime}$ terminal nucleotide of a small RNA is anchored in the phosphate-binding pocket of Argonaute proteins and unavailable for base pairing with its RNA target (Ma et al. 2005; Parker et al. 2005). We speculate that the structures of Ago1 and Ago2 discriminate between $U$ and $C$ by making specific hydrogen-bonding contacts with the edges of the first base of a small RNA guide.

The fate of a miRNA/miRNA* duplex, therefore, depends on multiple factors: structure of its duplex, thermodynamic stability of the ends of the duplex and the identity of its $5^{\prime}$ terminal nucleotide. We do not yet know to what extent each factor weighs in the sorting decision.

miRNA loci appear to generate an extraordinary diversity of functional small RNAs. Some miRNA genes are transcribed from both DNA strands, producing two different hairpins from a single genomic locus (Stark et al. 2008; Tyler et al. 2008). A few miRNA have been annotated as producing functional small RNAs-miRNA-5p and
miRNA-3p-from a single pre-miRNA, a phenomenon that we suggest may be the rule rather than the exception. Our data argue that the two small RNAs, typically annotated as miRNA and miRNA*, from a single pre-miRNA partition into distinct effector proteins, with the miRNA loading into Agol and the miRNA* loading into Ago2. These Ago2-loaded miRNA*s are present at levels comparable to exo-siRNAs. Moreover, Ago2-loaded small RNAs can guide either target cleavage or translational repression (Iwasaki et al. 2009), suggesting that Ago2-loaded miRNA*s function to regulate as yet to be identified target RNAs. Finally, we find that a single arm of a single pre-miRNA hairpin can give rise to several functional RNA isoforms that possess different seed sequence and that associate with different Argonaute proteins that have distinct biological activities. These three layers of functional diversificationmultiple small RNAs that partition differently from the two sides of the stem of a single pre-miRNA, different seed isoforms from a single side of a pre-miRNA stem, and distinct partitioning of these RNA seed isoforms-allows a single, compact genomic locus, the miRNA gene, to produce multiple riboregulators, each with a distinct biological activity and target repertoire.

\section{MATERIALS AND METHODS}

\section{General methods}

Fly strains were wild-type Oregon $\mathrm{R}, d c r-2^{L 811 f_{s} X}, r 2 d 2^{1}$, and ago $2^{414}$. Fly heads were isolated by vigorous shaking of liquid nitrogen-frozen flies in nested, prechilled sieves (U.S.A. standard sieve, Humboldt MFG), allowing the heads to pass through the top sieve (No. 25), and collecting them on the bottom sieve (No. 40).

\section{Small RNA sequencing}

Total RNA was extracted with the mirVana kit (Ambion), then 18-30-nt-long RNA was gel purified. $2 \mathrm{~S}$ rRNA was depleted as 
described (Seitz et al. 2008). A part of the sample was then oxidized using sodium periodate (Horwich et al. 2007) without $\beta$-elimination step. Size-selected RNA derived from at least $68 \mu \mathrm{g}$ total RNA for oxidation; and size-selected RNA derived from at least $7 \mu \mathrm{g}$ total RNA for untreated. Library preparation was as described previously (Ghildiyal et al. 2008). High-throughput sequencing was by Genome Analyzer II (Illumina). Raw high throughput sequencing data sets have been deposited at the National Center for Biotechnology Information Short Read Archive (www.ncbi.nlm.nih.gov/sites/sra) as GSE18806.

\section{Preparation of fly head extract}

Isolated fly heads were transferred to $1.5 \mathrm{~mL}$ microcentrifuge tubes, prechilled in liquid nitrogen, and homogenized using a plastic "pellet pestle" (Kontes) in $1 \mathrm{~mL}$ ice-cold Lysis buffer (100 $\mathrm{mM}$ potassium acetate, $30 \mathrm{mM}$ HEPES-KOH at $\mathrm{pH} \mathrm{7.4,}$ $2 \mathrm{mM}$ magnesium acetate) containing $5 \mathrm{mM}$ DTT and $1 \mathrm{mg} / \mathrm{mL}$ complete "mini" EDTA-free protease inhibitor tablets (Roche Applied Science) per gram of heads. Lysate was clarified by centrifugation at $14,000 \mathrm{~g}$ for $30 \mathrm{~min}$ at $4^{\circ} \mathrm{C}$. The supernatant was dispensed into prechilled microcentrifuge tubes, flash frozen in liquid nitrogen, and stored at $-80^{\circ} \mathrm{C}$. Total protein concentration was determined by Bradford assay.

\section{Immunoprecipitation}

For small RNA cloning, immunoprecipitation of Agol protein was essentially as described (Miyoshi et al. 2005). Briefly, $40 \mu \mathrm{L}$ GammaBind beads (GE Healthcare: \#17-0885-01) were washed four times with $1 \mathrm{~mL}$ of Lysis buffer with DTT and protease inhibitors and containing $0.5 \% \mathrm{v} / \mathrm{v} \mathrm{NP}-40$, then incubated with $40 \mu \mathrm{L}$ monoclonal anti-Agol antibody (Miyoshi et al. 2005) in $1 \mathrm{~mL}$ Lysis buffer at $4^{\circ} \mathrm{C}$ for $3 \mathrm{~h}$. After washing five times with $1 \mathrm{~mL}$ of Lysis-IP buffer, the antibody-bound beads were incubated with $910 \mu \mathrm{L}$ fly head lysate $(\sim 4.55 \mathrm{mg}$ total protein $)$ at $4^{\circ} \mathrm{C}$ for $16 \mathrm{~h}$, and then the supernatant collected and the beads washed five times with $1 \mathrm{~mL}$ of RIPA buffer $(50 \mathrm{mM}$ Tris [pH 8.0], $1.0 \% \mathrm{v} / \mathrm{v}$ NP-40, $150 \mathrm{mM} \mathrm{NaCl}, 0.5 \%$ v/v DOC, $0.1 \%$ v/v SDS, 1X CompleteEDTA-free protease inhibitor cocktail tablet). Immunoprecipitation efficiency was confirmed by Western blotting.

\section{UV cross-linking}

UV cross-linking was performed in embryo lysates prepared as described (Tuschl et al. 1999). Embryo lysates were immunodepleted for Agol as described above. UV cross-linking was as previously described (Tomari et al. 2007), except that the samples were $\sim 0.5 \mathrm{~cm}$ from the UV lamp.

\section{Computational analyses}

For each sequence read, the first occurrence of the hexamer perfectly matching the $5^{\prime}$ end of the $3^{\prime}$ linker was identified. Sequences without a linker match were discarded. The extracted inserts for sequences that contained the $3^{\prime}$ linker were then mapped to the Drosophila melanogaster genome (Release R5.5). Inserts that matched perfectly and completely to the genome were collected using Bowtie (Langmead et al. 2009), and the corresponding genomic coordinates were determined for downstream functional analysis. Sequences corresponding to pre-miRNA hair- pins (miRBase, 13.0) or noncoding RNAs (ncRNAs; Supplemental Table S3) were identified using the same suffix tree-based software. Genes were retrieved from FlyBase (R5.5). We manually curated mature miRNA*. Mature miRNA annotations were obtained from miRBase (13.0). We allowed sequence reads to differ in $5^{\prime}$ and $3^{\prime}$ ends from mature miRNA or miRNA* for up to 9 nt. Endogenous siRNA (endo-siRNA) were defined as genome mapping 21-mers detected in the oxidized library and that did not map to ncRNA or miRNA hairpins. Exogenous siRNA (exosiRNA) were 21-mers detected in the oxidized library and that mapped perfectly to the white inverted repeat. Except for Fisher's exact test, which requires raw sequence reads, all sequence reads are reported in parts per million reads of sequencing depth, with the sequencing depth defined as total number of linker containing, genome-matching reads excluding ncRNAs.

Fisher's exact test was applied to each miRNA or miRNA* to identify those that are enriched in Agol or Ago2. Take miR-1 as an example, the $2 \times 2$ contingency table includes the following cells: number of reads of miR-1 detected in the library prepared from the Agol immunoprecipitate, number of reads of all other miRNA or miRNA* in this library, number of reads of miR-1 in the library prepared from oxidized small RNA, and number of reads of all other miRNA or miRNA* in the oxidized library. $P$-values $\leq 0.01$ were deemed significant. Furthermore, we required a miRNA or miRNA* enriched in an Argonaute protein to be at least $10 \mathrm{ppm}$ in that Ago. Enrichment score (Fig. 1B) was defined as the number of reads of a particular miRNA or miRNA* in one Argonaute versus the other. A pseudocount (or an uninformed prior in Bayesian statistics) of $10 \mathrm{ppm}$ was used to control noise arising from extremely low abundance. For example, for miR-1 the enrichment score was [(number of miR-1 reads in Agol +10$) /($ total number of all miRNA reads in Agol +10$)] /$ [(number of miR-1 in Ago $2+10) /($ total number of all miRNA reads in Ago $2+10)$ ]. Similarly, the fold change in a mutant compared with the wild type, again using miR-1 as an example, was defined as (number of miR-1 reads in the mutant +10 )/(total number of miR-1 reads in the wild-type +10 ), where $10 \mathrm{ppm}$ was the pseudocount.

Pairing probabilities were calculated using RNAcofold (ViennaRNA-1.8.3, http://www.tbi.univie.ac.at/RNA/). For each Argonaute-enriched miRNA or miRNA*, the most abundant isoform for that miRNA or miRNA* was chosen to be the guide strand and the corresponding passenger was taken to be the most abundant isoform of the miRNA* or miRNA from the wild-type untreated experiment (see Supplemental Discussion for empirical support for this approach). Both the guide and passenger were required to pass the aforementioned $10 \mathrm{ppm}$ threshold. The probability per position was the sum of the pairing probabilities for that position. Pairing probability for each position was smoothed by the values of the two neighboring nucleotides. For each position, we tested the significance of the difference between all Ago1-enriched miRNA and miRNA* together and all Ago2enriched miRNA and miRNA* together using the two-sided Wilcoxon ranked-sum test with 0.01 as the threshold for significance.

To compute first nucleotide bias, we used an egalitarian weighting scheme to account for the difference in transcriptional and processing efficiency for different miRNA and miRNA*. The isoforms for a particular miRNA or miRNA* were weighted by their abundance 
in a data set, then all miRNA and miRNA* were weighted equally. Because white exo-siRNAs are produced from the same transcript, we weighted all exo-siRNA sequences by their abundance.

\section{SUPPLEMENTAL MATERIAL}

Supplemental material can be found at http://www.rnajournal.org.

\section{ACKNOWLEDGMENTS}

We thank Alicia Boucher for assistance with fly husbandry, Gwen Farley for technical assistance, and members of the Zamore and Weng laboratories for advice, suggestions, and critical comments on the text. This work was supported in part by grants from the National Institutes of Health to P.D.Z. (GM62862 and GM65236).

Received October 12, 2009; accepted October 22, 2009.

\section{REFERENCES}

Ameres SL, Martinez J, Schroeder R. 2007. Molecular basis for target RNA recognition and cleavage by human RISC. Cell 130: 101-112.

Bernstein E, Caudy AA, Hammond SM, Hannon GJ. 2001. Role for a bidentate ribonuclease in the initiation step of RNA interference. Nature 409: 363-366.

Bohnsack MT, Czaplinski K, Gorlich D. 2004. Exportin 5 is a Ran GTP-dependent dsRNA-binding protein that mediates nuclear export of pre-miRNAs. RNA 10: 185-191.

Chendrimada TP, Gregory RI, Kumaraswamy E, Norman J, Cooch N, Nishikura K, Shiekhattar R. 2005. TRBP recruits the Dicer complex to Ago2 for microRNA processing and gene silencing. Nature 436: 740-744.

Chung WJ, Okamura K, Martin R, Lai EC. 2008. Endogenous RNA interference provides a somatic defense against Drosophila transposons. Curr Biol 18: 795-802.

Czech B, Malone CD, Zhou R, Stark A, Schlingeheyde C, Dus M, Perrimon N, Kellis M, Wohlschlegel JA, Sachidanandam R, et al. 2008. An endogenous small interfering RNA pathway in Drosophila. Nature 453: 798-802.

Denli AM, Tops BB, Plasterk RH, Ketting RF, Hannon GJ. 2004. Processing of primary microRNAs by the Microprocessor complex. Nature 432: 231-235.

Förstemann K, Tomari Y, Du T, Vagin VV, Denli AM, Bratu DP, Klattenhoff C, Theurkauf WE, Zamore PD. 2005. Normal microRNA maturation and germ-line stem cell maintenance requires Loquacious, a double-stranded RNA-binding domain protein. PLoS Biol 3: e236. doi: 10.1016/j.cell.2007.05.056.

Förstemann K, Horwich MD, Wee L, Tomari Y, Zamore PD. 2007. Drosophila microRNAs are sorted into functionally distinct argonaute complexes after production by dicer-1. Cell 130: 287-297.

Ghildiyal M, Zamore PD. 2009. Small silencing RNAs: An expanding universe. Nat Rev Genet 10: 94-108.

Ghildiyal M, Seitz H, Horwich MD, Li C, Du T, Lee S, Xu J, Kittler EL, Zapp ML, Weng Z, et al. 2008. Endogenous siRNAs derived from transposons and mRNAs in Drosophila somatic cells. Science 320: 1077-1081.

Gregory RI, Yan KP, Amuthan G, Chendrimada T, Doratotaj B, Cooch N, Shiekhattar R. 2004. The Microprocessor complex mediates the genesis of microRNAs. Nature 432: 235-240.

Grimson A, Farh KK, Johnston WK, Garrett-Engele P, Lim LP, Bartel DP. 2007. MicroRNA targeting specificity in mammals: Determinants beyond seed pairing. Mol Cell 27: 91-105.

Grishok A, Pasquinelli AE, Conte D, Li N, Parrish S, Ha I, Baillie DL, Fire A, Ruvkun G, Mello CC. 2001. Genes and mechanisms related to RNA interference regulate expression of the small temporal RNAs that control C. elegans developmental timing. Cell 106: 23-34.
Grun D, Wang YL, Langenberger D, Gunsalus KC, Rajewsky N. 2005. microRNA target predictions across seven Drosophila species and comparison to mammalian targets. PLoS Comput Biol 1: e13. doi: 10.1371/journal.pcbi.0010013.

Haley B, Zamore PD. 2004. Kinetic analysis of the RNAi enzyme complex. Nat Struct Mol Biol 11: 599-606.

Hammond SM, Bernstein E, Beach D, Hannon GJ. 2000. An RNAdirected nuclease mediates post-transcriptional gene silencing in Drosophila cells. Nature 404: 293-296.

Han J, Lee Y, Yeom KH, Kim YK, Jin H, Kim VN. 2004. The DroshaDGCR8 complex in primary microRNA processing. Genes \& Dev 18: 3016-3027.

Han J, Lee Y, Yeom KH, Nam JW, Heo I, Rhee JK, Sohn SY, Cho Y, Zhang BT, Kim VN. 2006. Molecular basis for the recognition of primary microRNAs by the Drosha-DGCR8 complex. Cell 125: 887-901.

Horwich MD, Li C, Matranga C, Vagin V, Farley G, Wang P, Zamore PD. 2007. The Drosophila RNA methyltransferase, DmHen1, modifies germline piRNAs and single-stranded siRNAs in RISC. Curr Biol 17: 1265-1272.

Hutvágner G, McLachlan J, Pasquinelli AE, Balint É, Tuschl T, Zamore PD. 2001. A cellular function for the RNA-interference enzyme Dicer in the maturation of the let-7 small temporal RNA. Science 293: 834-838.

Iwasaki S, Kawamata T, Tomari Y. 2009. Drosophila argonaute1 and argonaute2 employ distinct mechanisms for translational repression. Mol Cell 34: 58-67.

Jackson AL, Bartz SR, Schelter J, Kobayashi SV, Burchard J, Mao M, Li B, Cavet G, Linsley PS. 2003. Expression profiling reveals offtarget gene regulation by RNAi. Nat Biotechnol 21: 635-637.

Jackson AL, Burchard J, Schelter J, Chau BN, Cleary M, Lim L, Linsley PS. 2006. Widespread siRNA 'off-target' transcript silencing mediated by seed region sequence complementarity. RNA 12: $1179-1187$.

Jiang F, Ye X, Liu X, Fincher L, McKearin D, Liu Q. 2005. Dicer-1 and R3D1-L catalyze microRNA maturation in Drosophila. Genes \& Dev 19: 1674-1679.

Kawamata T, Seitz H, Tomari Y. 2009. Structural determinants of miRNAs for RISC loading and slicer-independent unwinding. Nat Struct Mol Biol 16: 953-960.

Kawamura Y, Saito K, Kin T, Ono Y, Asai K, Sunohara T, Okada TN, Siomi MC, Siomi H. 2008. Drosophila endogenous small RNAs bind to Argonaute 2 in somatic cells. Nature 453: 793-797.

Ketting RF, Fischer SE, Bernstein E, Sijen T, Hannon GJ, Plasterk RH. 2001. Dicer functions in RNA interference and in synthesis of small RNA involved in developmental timing in C. elegans. Genes \& Dev 15: 2654-2659.

Khvorova A, Reynolds A, Jayasena SD. 2003. Functional siRNAs and miRNAs exhibit strand bias. Cell 115: 209-216.

Kim K, Lee YS, Carthew RW. 2006. Conversion of pre-RISC to holoRISC by Ago2 during assembly of RNAi complexes. RNA 13: 22 29.

Krek A, Grun D, Poy MN, Wolf R, Rosenberg L, Epstein EJ, MacMenamin P, da Piedade I, Gunsalus KC, Stoffel M, et al. 2005. Combinatorial microRNA target predictions. Nat Genet 37: 495-500.

Lagos-Quintana M, Rauhut R, Lendeckel W, Tuschl T. 2001. Identification of novel genes coding for small expressed RNAs. Science 294: 853-858.

Langmead B, Trapnell C, Pop M, Salzberg SL. 2009. Ultrafast and memory-efficient alignment of short DNA sequences to the human genome. Genome Biol 10: R25. doi: 10.1186/gb-2009-10-3-r25.

Lau NC, Lim LP, Weinstein EG, Bartel DP. 2001. An abundant class of tiny RNAs with probable regulatory roles in Caenorhabditis elegans. Science 294: 858-862.

Lee RC, Ambros V. 2001. An extensive class of small RNAs in Caenorhabditis elegans. Science 294: 862-864.

Lee YS, Carthew RW. 2003. Making a better RNAi vector for Drosophila: Use of intron spacers. Methods 30: 322-329. 
Lee Y, Ahn C, Han J, Choi H, Kim J, Yim J, Lee J, Provost P, Radmark O, Kim S, et al. 2003. The nuclear RNase III Drosha initiates microRNA processing. Nature 425: 415-419.

Lee YS, Nakahara K, Pham JW, Kim K, He Z, Sontheimer EJ, Carthew RW. 2004. Distinct roles for Drosophila Dicer-1 and Dicer-2 in the siRNA/miRNA silencing pathways. Cell 117: 69-81.

Lee Y, Hur I, Park SY, Kim YK, Suh MR, Kim VN. 2006. The role of PACT in the RNA silencing pathway. EMBO J 25: 522-532.

Leuschner PJ, Ameres SL, Kueng S, Martinez J. 2006. Cleavage of the siRNA passenger strand during RISC assembly in human cells. EMBO Rep 7: 314-320.

Lewis BP, Shih IH, Jones-Rhoades MW, Bartel DP, Burge CB. 2003. Prediction of mammalian microRNA targets. Cell 115: 787-798.

Lewis BP, Burge CB, Bartel DP. 2005. Conserved seed pairing, often flanked by adenosines, indicates that thousands of human genes are microRNA targets. Cell 120: 15-20.

Lim LP, Lau NC, Garrett-Engele P, Grimson A, Schelter JM, Castle J, Bartel DP, Linsley PS, Johnson JM. 2005. Microarray analysis shows that some microRNAs downregulate large numbers of target mRNAs. Nature 433: 769-773.

Lin EA, Kong L, Bai XH, Luan Y, Liu CJ. 2009. miR-199a, a bone morphogenic protein 2-responsive MicroRNA, regulates chondrogenesis via direct targeting to Smad1. J Biol Chem 284: 11326-11335.

Liu Q, Rand TA, Kalidas S, Du F, Kim HE, Smith DP, Wang X. 2003. R2D2, a bridge between the initiation and effector steps of the Drosophila RNAi pathway. Science 301: 1921-1925.

Lund E, Guttinger S, Calado A, Dahlberg JE, Kutay U. 2004. Nuclear export of microRNA precursors. Science 303: 95-98.

Ma JB, Yuan YR, Meister G, Pei Y, Tuschl T, Patel DJ. 2005. Structural basis for $5^{\prime}$-end-specific recognition of guide RNA by the A. fulgidus Piwi protein. Nature 434: 666-670.

Maniataki E, Mourelatos Z. 2005. A human, ATP-independent, RISC assembly machine fueled by pre-miRNA. Genes \& Dev 19: 2979-2990.

Matranga C, Tomari Y, Shin C, Bartel DP, Zamore PD. 2005. Passenger-strand cleavage facilitates assembly of siRNA into Ago2-containing RNAi enzyme complexes. Cell 123: 607-620.

Melo SA, Ropero S, Moutinho C, Aaltonen LA, Yamamoto H, Calin GA, Rossi S, Fernandez AF, Carneiro F, Oliveira C, et al. 2009. A TARBP2 mutation in human cancer impairs microRNA processing and DICER1 function. Nat Genet 41: 365-370.

Mi S, Cai T, Hu Y, Chen Y, Hodges E, Ni F, Wu L, Li S, Zhou H, Long C, et al. 2008. Sorting of small RNAs into Arabidopsis argonaute complexes is directed by the $5^{\prime}$ terminal nucleotide. Cell 133: 116-127.

Miyoshi K, Tsukumo H, Nagami T, Siomi H, Siomi MC. 2005. Slicer function of Drosophila Argonautes and its involvement in RISC formation. Genes \& Dev 19: 2837-2848.

Montgomery TA, Howell MD, Cuperus JT, Li D, Hansen JE, Alexander AL, Chapman EJ, Fahlgren N, Allen E, Carrington JC. 2008. Specificity of ARGONAUTE7-miR390 interaction and dual functionality in TAS3 trans-acting siRNA formation. Cell 133: 128-141.

Okamura K, Ishizuka A, Siomi H, Siomi MC. 2004. Distinct roles for Argonaute proteins in small RNA-directed RNA cleavage pathways. Genes \& Dev 18: 1655-1666.

Okamura K, Hagen JW, Duan H, Tyler DM, Lai EC. 2007. The Mirtron Pathway Generates microRNA-Class Regulatory RNAs in Drosophila. Cell 130: 89-100.

Okamura K, Balla S, Martin R, Liu N, Lai EC. 2008a. Two distinct mechanisms generate endogenous siRNAs from bidirectional transcription in Drosophila melanogaster. Nat Struct Mol Biol 15: 581-590.

Okamura K, Chung WJ, Ruby JG, Guo H, Bartel DP, Lai EC. 2008b. The Drosophila hairpin RNA pathway generates endogenous short interfering RNAs. Nature 453: 803-806.

Okamura K, Phillips MD, Tyler DM, Duan H, Chou YT, Lai EC. 2008c. The regulatory activity of microRNA* species has substantial influence on microRNA and 3' UTR evolution. Nat Struct Mol Biol 15: 354-363.
Parker JS, Roe SM, Barford D. 2005. Structural insights into mRNA recognition from a PIWI domain-siRNA guide complex. Nature 434: 663-666.

Parker JS, Parizotto EA, Wang M, Roe SM, Barford D. 2009. Enhancement of the seed-target recognition step in RNA silencing by a PIWI/MID domain protein. Mol Cell 33: 204-214.

Rajewsky N, Socci ND. 2004. Computational identification of microRNA targets. Dev Biol 267: 529-535.

Rand TA, Ginalski K, Grishin NV, Wang X. 2004. Biochemical identification of Argonaute 2 as the sole protein required for RNA-induced silencing complex activity. Proc Natl Acad Sci 101: 14385-14389.

Rand TA, Petersen S, Du F, Wang X. 2005. Argonaute2 cleaves the anti-guide strand of siRNA during RISC activation. Cell 123: 621629

Ro S, Park C, Young D, Sanders KM, Yan W. 2007. Tissue-dependent paired expression of miRNAs. Nucleic Acids Res 35: 5944-5953.

Ruby JG, Jan CH, Bartel DP. 2007a. Intronic microRNA precursors that bypass Drosha processing. Nature 448: 83-86.

Ruby JG, Stark A, Johnston WK, Kellis M, Bartel DP, Lai EC. 2007b. Evolution, biogenesis, expression, and target predictions of a substantially expanded set of Drosophila microRNAs. Genome Res 17: $1850-1864$.

Saito K, Ishizuka A, Siomi H, Siomi MC. 2005. Processing of premicroRNAs by the Dicer-1-Loquacious complex in Drosophila cells. PLoS Biol 3: e235. doi: 10.1371/journal.pbio.0030235.

Saito K, Sakaguchi Y, Suzuki T, Suzuki T, Siomi H, Siomi MC. 2007. Pimet, the Drosophila homolog of HEN1, mediates 2'-O-methylation of Piwi- interacting RNAs at their $3^{\prime}$ ends. Genes \& Dev 21: 1603-1608.

Schwarz DS, Hutvágner G, Du T, Xu Z, Aronin N, Zamore PD. 2003. Asymmetry in the assembly of the RNAi enzyme complex. Cell 115: 199-208.

Seitz H, Ghildiyal M, Zamore PD. 2008. Argonaute loading improves the $5^{\prime}$ precision of both microRNAs and their miRNA* strands in flies. Curr Biol 18: 147-151.

Stark A, Bushati N, Jan CH, Kheradpour P, Hodges E, Brennecke J, Bartel DP, Cohen SM, Kellis M. 2008. A single Hox locus in Drosophila produces functional microRNAs from opposite DNA strands. Genes \& Dev 22: 8-13.

Tomari Y, Du T, Haley B, Schwarz DS, Bennett R, Cook HA, Koppetsch BS, Theurkauf WE, Zamore PD. 2004a. RISC assembly defects in the Drosophila RNAi mutant armitage. Cell 116: 831841.

Tomari Y, Matranga C, Haley B, Martinez N, Zamore PD. 2004b. A protein sensor for siRNA asymmetry. Science 306: 1377-1380.

Tomari Y, Du T, Zamore PD. 2007. Sorting of Drosophila small silencing RNAs. Cell 130: 299-308.

Tuschl T, Zamore PD, Lehmann R, Bartel DP, Sharp PA. 1999. Targeted mRNA degradation by double-stranded RNA in vitro. Genes \& Dev 13: 3191-3197.

Tyler DM, Okamura K, Chung WJ, Hagen JW, Berezikov E, Hannon GJ, Lai EC. 2008. Functionally distinct regulatory RNAs generated by bidirectional transcription and processing of microRNA loci. Genes \& Dev 22: 26-36.

Wang Y, Juranek S, Li H, Sheng G, Tuschl T, Patel DJ. 2008. Structure of an argonaute silencing complex with a seed-containing guide DNA and target RNA duplex. Nature 456: 921-926.

Yi R, Qin Y, Macara IG, Cullen BR. 2003. Exportin-5 mediates the nuclear export of pre-microRNAs and short hairpin RNAs. Genes \& Dev 17: 3011-3016.

Zamore PD, Tuschl T, Sharp PA, Bartel DP. 2000. RNAi: Doublestranded RNA directs the ATP-dependent cleavage of mRNA at 21 to 23 nucleotide intervals. Cell 101: 25-33.

Zeng Y, Yi R, Cullen BR. 2005. Recognition and cleavage of primary microRNA precursors by the nuclear processing enzyme Drosha. EMBO J 24: $38-48$. 

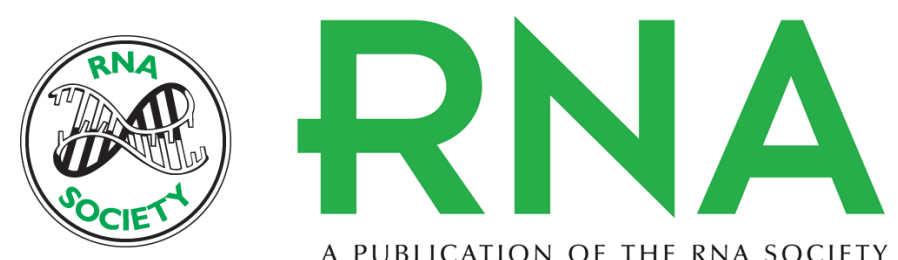

A PUBLICATION OF THE RNA SOCIETY

\section{Sorting of Drosophila small silencing RNAs partitions microRNA* strands into the RNA interference pathway}

Megha Ghildiyal, Jia Xu, Hervé Seitz, et al.

RNA 2010 16: 43-56 originally published online November 16, 2009

Access the most recent version at doi:10.1261/rna.1972910

\section{Supplemental http://rnajournal.cshlp.org/content/suppl/2009/11/06/rna.1972910.DC1 \\ Material}

References This article cites 80 articles, 25 of which can be accessed free at: http://rnajournal.cshlp.org/content/16/1/43.full.html\#ref-list-1

Open Access Freely available online through the RNA Open Access option.

License Freely available online through the RNA Open Access option.

Email Alerting Receive free email alerts when new articles cite this article - sign up in the box at the Service top right corner of the article or click here.

To subscribe to RNA go to:

http://rnajournal.cshlp.org/subscriptions 